\title{
Eco-Rehabilitation and Improvement of Water Plant and Animal Species
}

\author{
${ }^{1}$ Olga Yu. Derevenskaya, ${ }^{2}$ Angelina V. Pichugina, ${ }^{3}$ Nafisa M. Mingazova \\ ${ }^{1-3}$ Kazan Federal University \\ Email: oderevenskaya@mail.ru
}

Received: $2^{\text {th }}$ August 2019, Accepted: 30 ${ }^{\text {th }}$ September 2019, Published: $3^{\text {st }}$ October 2019

\begin{abstract}
From 2011 to 2013, in the water area of Kuibyshev Reservoir in the Kazan region (Russia), the artificial plots of land were created in the process of land reclamation. As a result, 600 hectares of flooded islands, breeding grounds, and channels were filled with sand. The system of artificial land plots was formed, connected with the existing islands. And the part of the Volga River, enclosed by them, turned into a relatively landlocked body of water. In the process of land reclamation, the destruction of the water body, fauna and flora of water area and islands was revealed.

The research, conducted in July-August 2018, revealed the "blooming" of water, intensifying at the end of summer, and leading to an increase in water $\mathrm{pH}$ (up to 9 units), and supersaturation of the surface layers of water with oxygen. Significant changes in the abundance and biomass of zooplankton, the dominance of indicator species of eutrophic waters, and disturbance of the community structure have been revealed. The zoobenthos community is characterized by a simplified structure, low values of quantitative indicators, and the dominance of a group, which is resistant to water pollution. According to the index of Woodiviss, the reservoir is "very dirty" - "dirty."

The draft project of eco-rehabilitation and improvement of the area was developed. The project provides for the scouring of channels, restoration of wood and shrubby vegetation, grass cover on reclaimed territories, strengthening of shore, creation of a road-path network, lighting, and recreation areas.
\end{abstract}

\section{Keywords}

Eco-rehabilitation, Hydraulic Filling, Reservoir, Eutrophication, Water Quality, Improvement.

\section{Introduction}

Provision of the population with water, the quality of water and the possibility of its improvement are currently the most acute problems in many countries of the world. Significant concentration of urban population, the sharp increase in industrial, agricultural, transport, energy and other anthropogenic emissions have led to the deterioration in water quality. Water bodies are under the influence of anthropogenic impacts of various types, including from reclamation works. In megacities, it is more profitable for the real estate developer to construct buildings on reclamation grounds, than to buy the plots of existing land. This is the reason for the creation of numerous sand areas, threatening the state of the environment. As a result of reclamation, the deep and long-term damage to the environment can be caused, and the self-cleaning ability of the reservoir can be significantly reduced. The implementation of hydraulic projects in the water areas of reservoirs, without a proper assessment of the environmental impact, can significantly worsen its ecological state, and create the problems with the provision of population with drinking water.

Kuibyshev reservoir is the largest artificial water body, created on the Volga River. The main purpose of the reservoir is to generate electricity, to improve shipping, the supply of water, irrigation, and fishing. From 2011 to 2013, the artificial plots of land were reclaimed in the water area of Kuibyshev reservoir, in Kazan (Russia). As a result of hydraulic filling, the system of artificial land plots was formed, connected with the existing islands, and the part of the Volga River, enclosed by them, turned into a relatively landlocked body of water.

The purpose of the work is to assess the state and to develop the recommendations for ecological rehabilitation of the territories, affected by a large-scale reclamation.

\section{Methods}

In July-August 2018, the field studies of Kuibyshev reservoir were conducted near the village Zaymishche (Fig. 1). The measurements of physical and chemical parameters of water (oxygen content, water temperature, $\mathrm{pH}$ ), the sampling of zooplankton and zoobenthos were performed. 


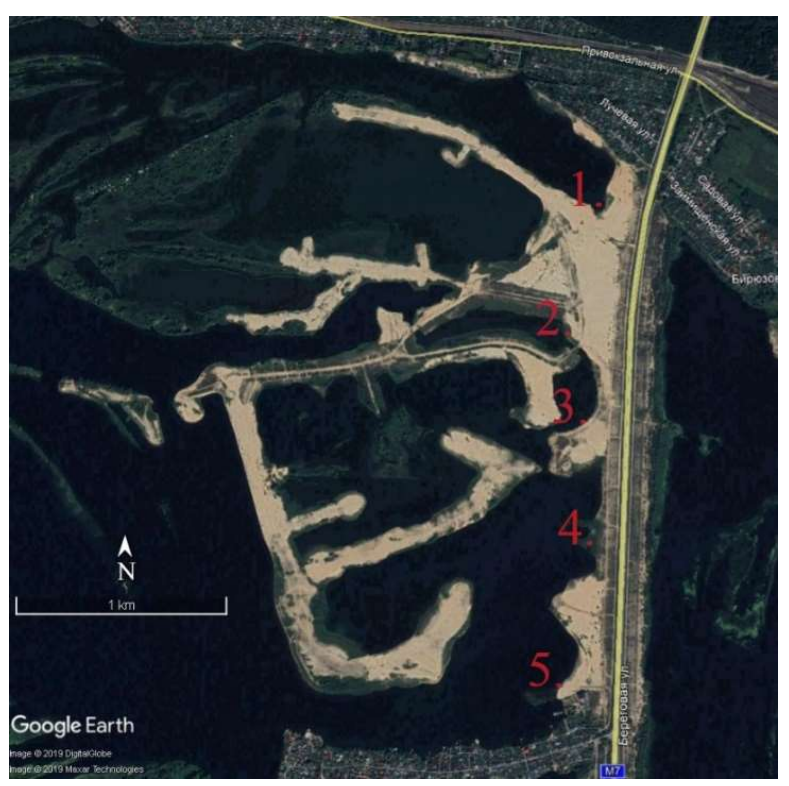

Fig. 1: Sampling Points.

Water temperature and oxygen content were measured using the dissolved oxygen meter "Mark 302E". Water $\mathrm{pH}$ was defined using the portable $\mathrm{pH}$ meter "Hanna" at the stations 1-5. Zooplankton samples were taken by filtering 501 of water through the Apstein net (mesh size $100 \mu \mathrm{m}$ ). Zoobenthos samples were taken in a shallow coastal zone from a site of $20 * 20 \mathrm{~cm}$, using a scraper; the soil was washed through the benthic net. The samples were fixed with $4 \%$ formalin. The laboratory investigations of hydrobiological samples were performed using the generally accepted methods [1,2]. To assess water quality, the index of saprobity [3] and the Shannon index [4] were estimated by zooplankton, and the index of Woodiviss - by zoobenthos.

The assessment of the effect of hydraulic fill on various environmental components was performed using the method of matrix analysis.

\section{Results and Discussion}

Land reclamation is the process of filling and draining the coastal zone, in order to expand the land area, available for development. The reclaimed ground is a natural and anthropogenic object, created as a result of purposeful human activities, to satisfy the needs of people. In the process of creation of new land area, the boundaries of the water body change, and the boundaries of its water protection zone shift $[5,6]$.

From 2011 to 2013 in Kazan, artificial plots of land were reclaimed in the water area of Kuibyshev Reservoir, in order to create new territories for the construction of a housing estate. According to the Kazan Inter-District Environmental Prosecutor's Office, around 500 hectares of flooded islands, breeding grounds, 15 channels were filled with sand. Filling was made by sand, with a layer up to two meters. In the process of land reclamation, the destruction of a water body, fauna and flora of the water area and islands was revealed.

The coastal territories and islands in this area were the habitats of a large number of plants and animal species, including those, listed in the Red Book of the Republic of Tatarstan. As a result of deepening the bottom under the shore and filling of channels between the islands, spawning shallow water was destroyed.

The creation of land plots and filling of part of the water area of Kuibyshev reservoir have led to a destruction of the landscape of this area, which was naturally formed during the existence of the reservoir and the ecological system. This fundamentally does not correspond to the basic canons of the water strategy of the Russian Federation [7].

Due to the measures of environmental activists and the local population, the works were stopped, and the prohibition on the construction of high-rise buildings in reclaimed territories was imposed. At present, this territory is considerably transformed. The space images show the difference between the structure of the river and islands a few years ago, and current situation, after a large-scale hydraulic filling of territories (Fig. 2-3). 


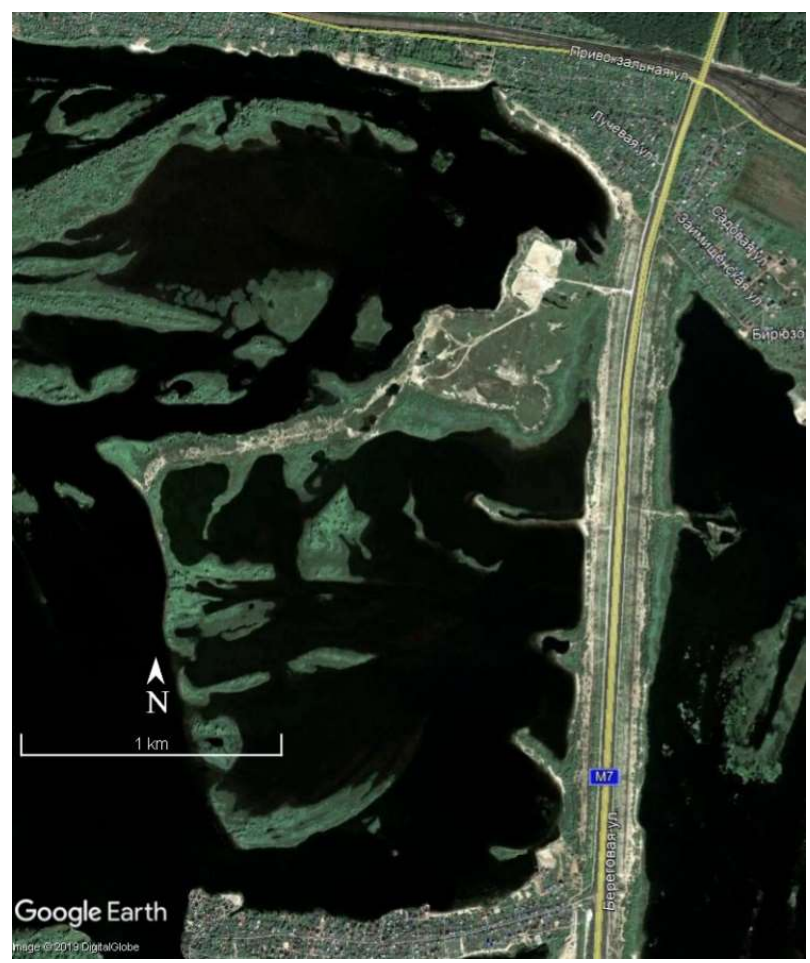

Fig. 2. Space Image, dated August 22, 2009

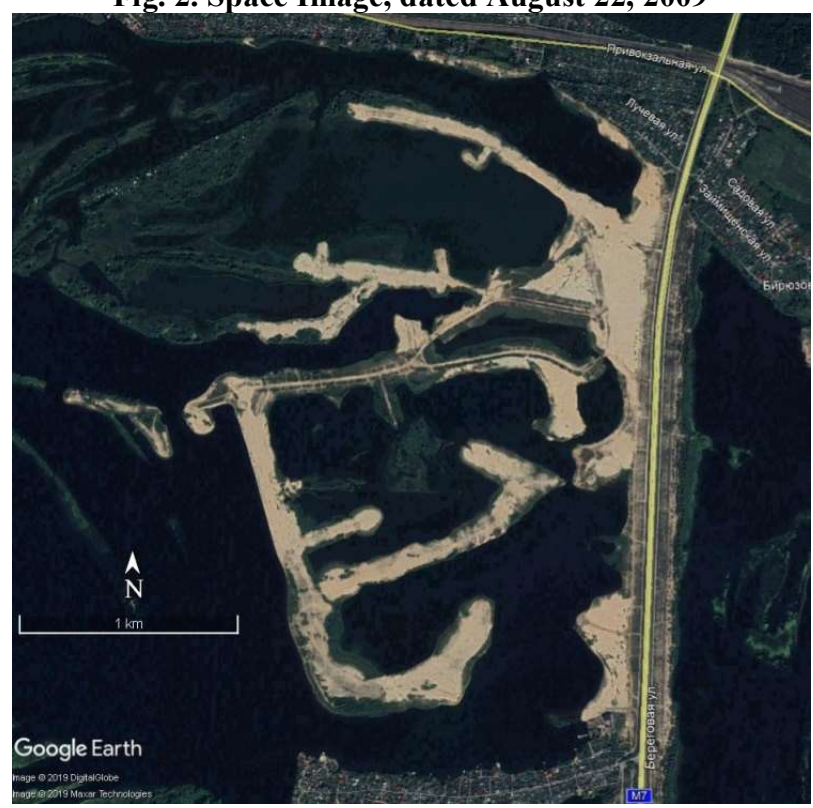

Fig. 3. Space Image, dated August 31, 2017.

The matrix analysis allowed to evaluate the consequences of the land reclamation on various environmental components. The greatest damage to the environmental components during the construction period is exerted by such factors as soil filling and sand washing (Table 1). The studies show that the landscape (8), soil (15), surface water (8), flora (8) and fauna (9) are the most influenced by different factors during the construction period. 


\begin{tabular}{|l|c|c|c|c|c|c|c|c|}
\hline Types of impact & Climate & Relief & Landscape & Soil & $\begin{array}{c}\text { Surface } \\
\text { water }\end{array}$ & $\begin{array}{c}\text { Ground } \\
\text { water }\end{array}$ & Flora & Fauna \\
\hline Soil filling & 0 & 2 & 1 & 5 & 1 & 1 & 1 & 2 \\
\hline Sand washing & 0 & 2 & 2 & 5 & 5 & 2 & 5 & 5 \\
\hline $\begin{array}{l}\text { Pollution from } \\
\text { construction } \\
\text { equipment }\end{array}$ & 0 & 1 & 1 & 3 & 1 & 0 & 1 & 0 \\
\hline Physical impact & 0 & 1 & 1 & 2 & 1 & 0 & 1 & 1 \\
\hline Noise impact & 0 & 0 & 0 & 0 & 0 & 0 & 0 & 1 \\
\hline Total & 0 & 6 & 5 & 15 & 8 & 3 & 8 & 9 \\
\hline
\end{tabular}

Table 1: The Matrix Analysis of the Impact of Hydraulic Filling on the Environmental Components

Note: Characteristics of impact levels: 0 - no impact; 1 - very weak; 2 - weak; 3 - average; 4 - strong; 5 - very strong impact.

Physicochemical studies of water showed that the water temperature in July-August 2018 was $23-26{ }^{\circ} \mathrm{C}$ at different stations. The water was well warmed, and this contributed to the emergence of water "blooming". The consequence of this was an increase in water $\mathrm{pH}$ (at some stations up to 9 units) and the content of dissolved oxygen (up to $270 \%$ ).

For the entire period of study, 37 species were identified in the composition of zooplankton, including Rotifera - 12 (32\%), Cladocera - 16 (43\%), Copepoda - 9 (24\%). Diaphanosoma orghidani Negrea, 1982, Brachionus diversicornis (Daday, 1883), Bosmina (B.) longirostris (O.F. Muller, 1785) and others dominated by dates and stations. Significant fluctuations in the abundance and biomass of zooplankton by stations have been revealed. This may be due to the dissimilar environmental conditions (for example, the presence or absence of flow). The abundance varied from 10.9 thousand individuals $/ \mathrm{m}^{3}$, to 2194.9 thousand individuals $/ \mathrm{m}^{3}$. In August, the abundance of zooplankton was higher. At the station 1, a large number of rotifers $B$. diversicornis, which were the indicators of dirty water, was present in the samples [8-10]. This caused a significant increase in the zooplankton abundance. The biomass of zooplankton varied from 0.067 to $4.9 \mathrm{~g} / \mathrm{m}^{3}$ and was higher in August. Biotic indices showed higher water quality in July, compared with August. According to the index of saprobity, water was "clean" in July, and "moderately contaminated" in August. The Shannon index values were relatively high in July (2.52 and 3.51), and very low in August (0.97 and 2.07). The decrease in biotic indices may be due to the deterioration in water quality, "blooming", and is more pronounced in August.

14 species, belonging to 3 types and 4 classes, were identified in zoobenthos. Among them, 11 species were Insecta, 1 Oligochaeta, 1 - Gastropoda, and 1 - Bivalvia. Chironomid larvae prevailed in terms of quality and quantity. The dominant complex was comprised by Cryptochironomus (Cryptochironomus) defectus (Kieffer, 1913), Endochironomus tendens (Fabricius, 1775), Chironomus dorsalis (Meigen, 1818), Paratanytarsuslauterborni (Kieffer, 1909) and Cladotanytarsus (Cladotanytarsus) mancus (Walker, 1856). Zoobenthos has a chironomid-oligochaete composition. The abundance of zoobenthos varied by stations from 0 to 425 individuals $/ \mathrm{m}^{2}$. The biomass of zoobenthos varied from 0.3 to $2.7 \mathrm{~g} / \mathrm{m}^{2}$. The values of Woodiviss index ranged from 0 to 2 - the water is "very dirty" - "dirty".

As a result of large-scale land reclamation, the ecological and recreational functions of territory were practically lost. In this area of the reservoir, there is a dysfunction of biological self-cleaning process. For its restoration, it is necessary to carry out the ecological rehabilitation of the water area and floodplain. The most important task is the restoration of hydrological balance, in particular, the scouring of channels, that will help to avoid the stagnation of water.

For the ecological rehabilitation of the reservoir, the following measures are proposed: the scouring of channels to restore or to improve the disturbed hydrological regime, as well as the restitution of natural depths; regeneration of tree and shrub vegetation on reclaimed territories; leveling and strengthening of coastal slopes, using geogrids; planting of macrophytes; restoration of grass cover on the territory, adjacent to the river; creation of nesting places for birds.

The features of islands configuration allow to determine the direction of the prevailing currents in this section, with a sufficient degree of certainty (Fig. 4). Before the reclamation of land in this area, three types of currents could be distinguished: 1. Midstream. 2. Subsidiary flow. 3. The currents of the inter-island channels. 


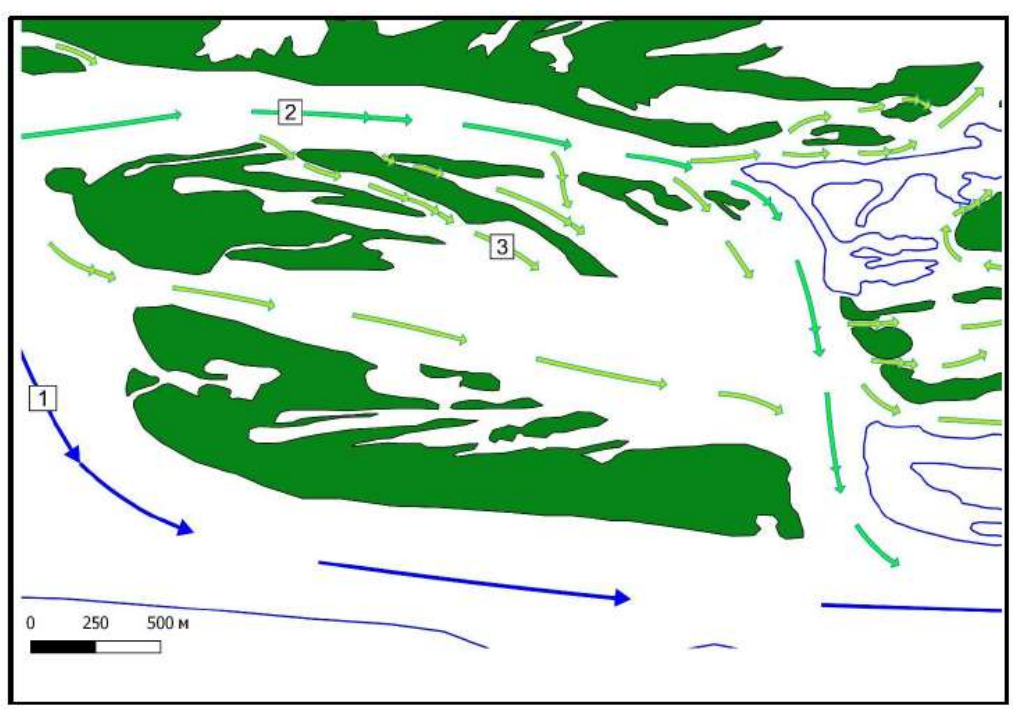

Fig. 4: The Types of Currents in the Studied Area (1 - Midstream, 2 - Subsidiary Flow, 3 - The Currents of the Inter-island Channels).

Having laid the image of prevailing directions of the former currents on the space image of the present-day situation (using the program SAS.Planet), the areas, where the land reclamation blocked the existing water flow and changed the ecological situation, can be determined (Fig. 5). Land reclamation changed the circulation of water in the channels between the islands, forming isolated bodies of water, which are characterized by low water quality.

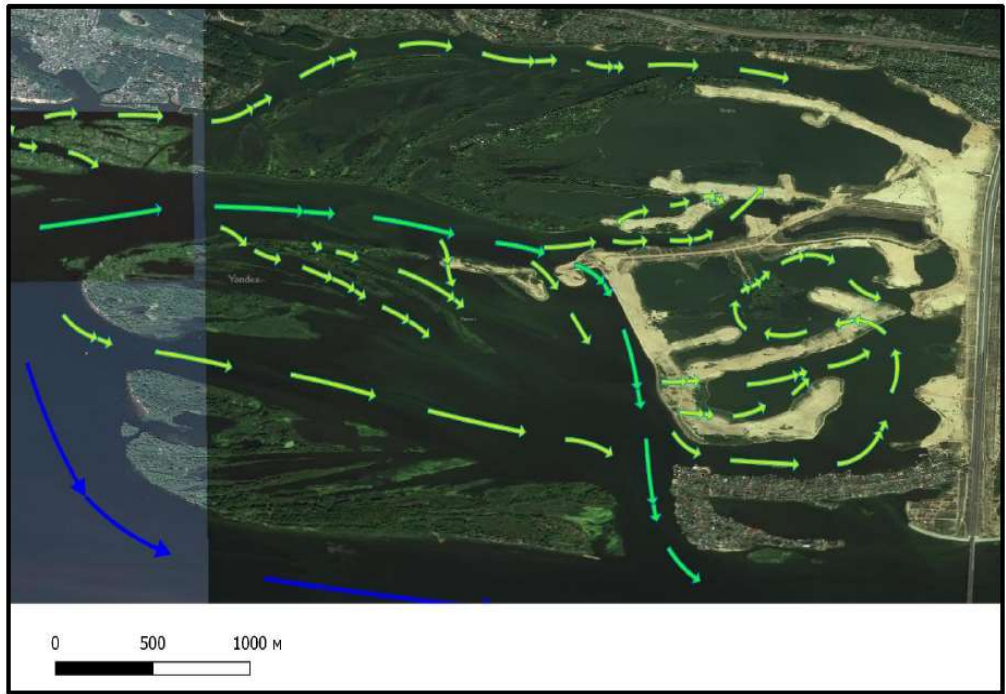

Fig. 5: The Zones of Blocked Water Flows in the Inter-island Channels.

To restore the previously existing water exchange, the authors of project recommend the clearing of channels in 10 locations (Fig. 6). 


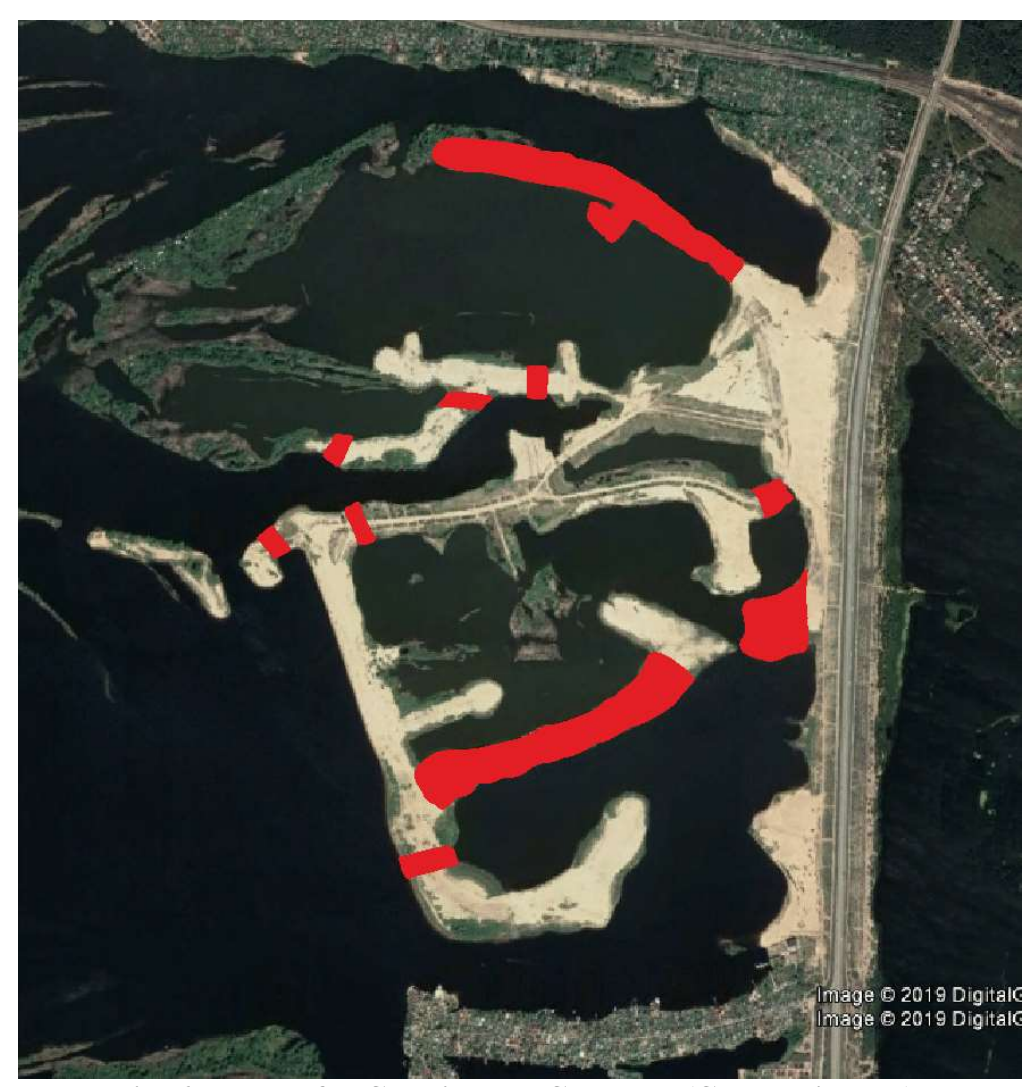

Fig. 6 : Places for Clearing the Channels (Colored in Red).

The soil, formed on the reclaimed ground, is sandy and has a number of serious drawbacks: it does not retain water well; it warms up quickly under sunlight, therefore it requires frequent watering; mechanical particles are poorly bound; nutrients are washed out with water and moved to lower horizons. Without the necessary preparation of sandy soil, most plants will constantly experience water shortages and they can die. On the territories with reclaimed soils, the surface runoff is provided. The additives in the form of composts or manure are added, which are embedded to a depth of $40 \mathrm{~cm}$ over the entire improved soil horizon, in order to increase its viscosity.

The next step is the sowing of seeds of plant-siderates. Phosphorus and potassium fertilizers are applied before sowing. The siderates not only enrich the soil with micronutrient elements, but also loosen the soil, making it able to absorb moisture quickly and to deliver oxygen to the root system. After the growing of grass stand and its burying in the soil, the areas are sown again with grass seeds. Such a procedure can be performed during two-three years.

It is also planned to take measures to restore the habitats of waterfowl: nesting in favorable biotopes. The extension of area of aquatic and coastal plants can serve as the important means of increasing the number of waterfowl, as well as semi-aquatic animals.

The project provides for the improvement of ecological situation on the islands, formed as a result of reclamation within the water area. The islands allow to increase the length of the coastline, that will lead to the emergence of new spawning grounds. Also, these islands can be sown with herbs, tree and shrubbery plantings.

So, after implementation of this complex of measures, the water quality will increase, due to the improvement of flowage and the creation of conditions for self-cleaning. The sanitary and environmentally favourable habitat will be created on the territory, adjacent to the river. This will allow to maintain the reservoir in good sanitary condition in the future.

At the next stage, the improvement of the coastal territory is planned (Fig. 7). The project, developed by us, includes various functional areas: places for short-term stay and rest of people; areas of quiet and active recreation; beach recreation; areas for children; rental areas; as well as the creation of developed network of highways and byways with hard surface; street lighting; parking area.

In order to reduce air pollution by exhaust gases near the reservoir, it is recommended to create dense protective landscaping (planting of trees) along the route. 


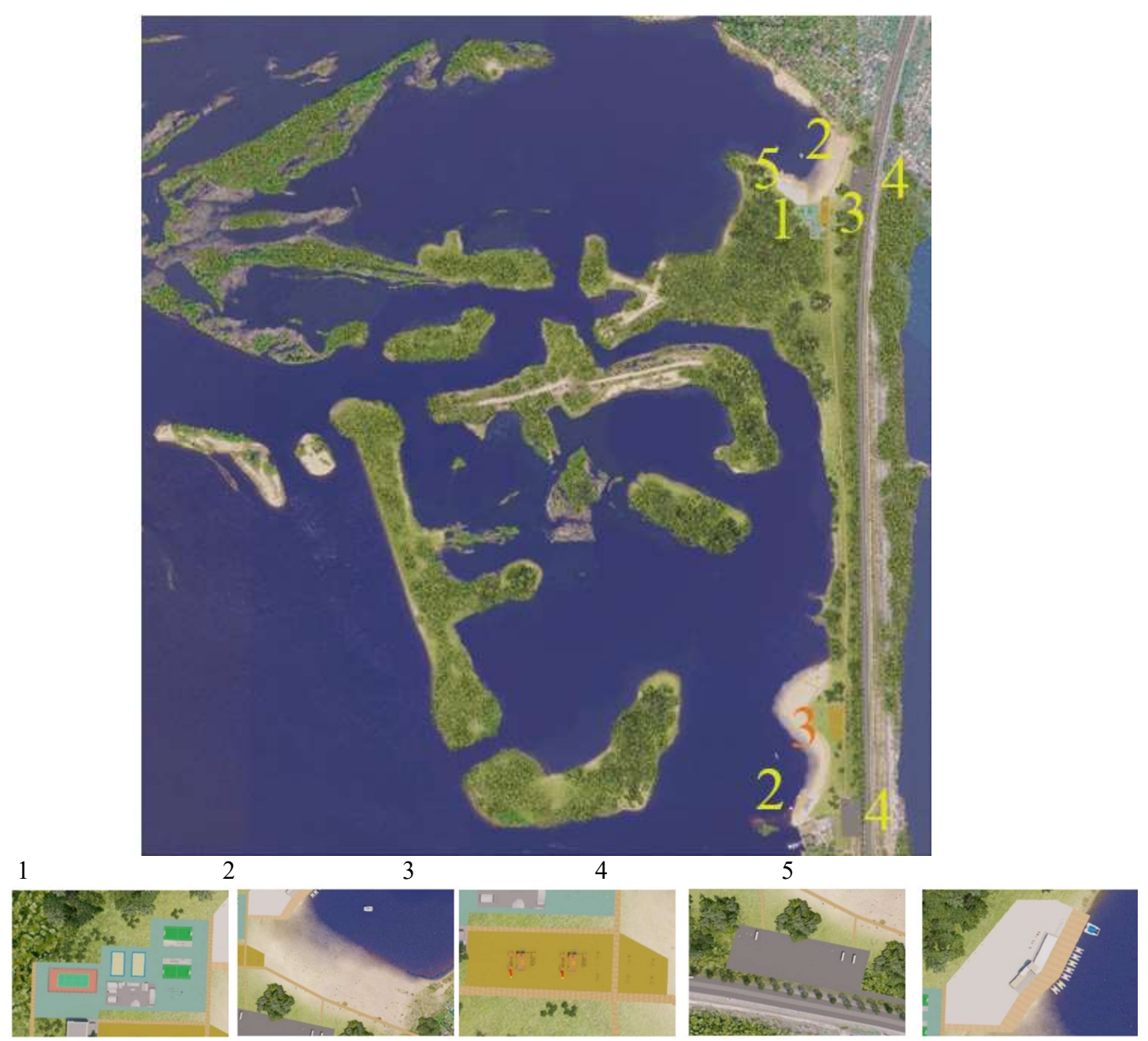

Fig. 7: The Master Plan of Landscaping Project. (1 - Zone of Active Recreation; 2 - Beach; 3 - Children's Playground; 4 - Zone of Car Parking; 5 - Zone of Boat Rental).

\section{Summary}

The research of territories, formed as a result of land reclamation in the water area of Kuibyshev reservoir, near the village Zaymishche, has revealed a number of problems: the changes of landscape, water logging, accumulation of municipal solid waste, lack of development of the coastal area. The matrix-scoring method of investigation showed, that the greatest impact on the environmental components, during the period of land reclamation, was caused by the soil filling and sand washing. The landscape (8), soil (15), surface water (8), flora (8) and fauna (9) were the most influenced by different factors.

The studies of Kuibyshev reservoir near the village Zaymishche have revealed the "blooming" of water, intensifying at the end of summer. The consequence of this phenomenon was the increase in water $\mathrm{pH}$ (up to 9 units), and supersaturation of the surface layers of water with oxygen. Significant fluctuations in the abundance and biomass of zooplankton by dates and stations, the dominance of indicator species of eutrophic waters, and disturbance of the community structure have been revealed. The zoobenthos community is characterized by a simplified structure, low values of quantitative indicators, and the dominance of a group, which is resistant to water pollution. According to the index of Woodiviss, the reservoir is "very dirty" - "dirty".

The project was created for improvement of ecological state of the water body, eco-rehabilitation of disturbed areas, and development of coastal zone. The project of eco-rehabilitation of the water area provides for the scouring of channels, restoration of wood and shrubby vegetation, grass cover, strengthening of shore, creation of conditions for the nesting of waterfowl. The development of territory involves the formation of a road-path network, street lighting, and zones for various types of recreation. 


\section{Conclusions}

In the process of land reclamation the spawning grounds and habitats of waterfowl are disturbed; the abundance of bottom invertebrates is reduced. Isolated parts of the river become boggy, flora and fauna die, biological resources are damaged. Land reclamation destroys the shallow waters, cleaning the river. This leads to intensive "blooming" of water, caused by phytoplankton.

Kuibyshev reservoir is the most important water body in Russia. It has drinking and fishery significance. Filling of shallow waters and the creation of artificial territories reduced the self-cleaning ability of the river, contributed to the emergence of water "blooming" in the newly formed bay. Poor quality of water in the river can threaten public health. To reduce the environmental risk, it is necessary to implement the project of environmental rehabilitation and subsequent development of the coastal zone.

\section{Acknowledgements}

The work is performed according to the Russian Government Program of Competitive Growth of Kazan Federal University.

We express our deep gratitude to Assoc. Professor, Candidate of Geographic Sciences, I.S. Shigapov for the provided materials of hydrological studies of Kuybyshev Reservoir, near the village Zaymishche.

\section{References}

[1] Methodological recommendations on the collection and processing of materials for the hydrobiological research in freshwater bodies. Zooplankton and its products. - L.: Zoological Institute of the Academy of Sciences of the USSR Berg State Research Institute on Lake and River Fisheries (GosNIORH), 1982. - 33 p.

[2] Guideline for the methods of hydrobiological analysis of surface waters and bottom sediments / Edited by A.B. Abakumov. - L.: Gidrometeoizdat, 1983. - 240 p.

[3] V. Sladečhek. System of water quality from biological point of view. Egetnisse der Limnologie, vol. 7, 1973. - 218 p.

[4] C.E. Shannon, W. Weaver. The mathematical theory of communication. Urbana: Univ. Illinois Press, 1949. - 117 p.

[5] N.N. Melnikov Theoretical problems of the inter-branch mechanism of legislative regulation in the field of creation and operation of artificial plots of ground // Proceedings of the Institute of State and Law of the Russian Academy of Sciences, 2015. Pp. 143-154.

[6] Grin E.A., Malimonova A.S. Artificial plot of land: problems of terminology // Young Scientist, 2015. Pp. 470-472.

[7] Water Code of the Russian Federation, dated June 03, 2006, No. 74-FZ (as amended on July 29, 2017).

[8] L. Hakkari. Zooplankton species as indicators of environment, Aquafennica, Helsinki, pp. 46-54, 1972.

[9] O. Derevenskaya, E. Unkovskaya, M. Kosova. Indices of zooplankton in assessing the ecological state of lake Ilinskoe (Russia). Turkish Online Journal of Design Art and Communication, vol. 7, special edition, pp. 1787-1794, 2017.

[10] J. Ejsmont-Karabin, A. Karabin. The suitability of zooplankton as lake ecosystem indicators: crustacean trophic state index, Polish Journal of Ecology (Pol. J. Ecol.), vol. 61, № 3, pp. 561-573, 2013. 